\title{
A Comparison of Mechanical Properties and Hydrogen Embrittlement Resistance of Austempered vs Quenched and Tempered 4340 Steel
}

JOHN M. TARTAGLIA, KRISTEN A. LAZZARI, GRACE P. HUI, and KATHY L. HAYRYNEN

DOI: $10.1007 / \mathrm{s} 11661-008-9521-6$

(C) The Minerals, Metals \& Materials Society and ASM International 2008

Erratum to: METALLURGICAL AND MATERIALS

TRANSACTIONS A, Vol. 39A, No. 3, March 2008

DOI 10.1007/s11661-007-9451-8

THE footnotes for Table III were inadvertently omitted from the original article:

Approximate UTS values: ${ }^{[24]}$

*Austempered: $1580 \mathrm{MPa}(229 \mathrm{ksi})$.

**Q\&T: $1450 \mathrm{MPa}(210 \mathrm{ksi})$.

Also, in the caption for Figure 3, the Mo content should have read 0.32 percent $\mathrm{Mo}$, as opposed to 0.23 percent Mo.

JOHN M. TARTAGLIA, Engineering Manager and Senior Metallurgical Engineer, and KRISTEN A. LAZZARI and GRACE P. HUI, Engineering Associates, are with Stork Climax Research Services, Wixom, MI 48393. Contact e-mail: john.tartaglia@ stork.com. KATHY L. HAYRYNEN, Technical Director, is with the Technologies Division, Applied Process, Inc., Livonia 48150, MI. The online version of the original article can be found under doi: 10.1007/s11661-007-9451-8.

Article published online March 18, 2008 